\title{
$d$ - $\alpha$-Tocopheryl Polyethylene Glycol-1000 Succinate Enhances the Absorption of Vitamin D in Chronic Cholestatic Liver Disease of Infancy and Childhood
}

\author{
ERIC A. ARGAO, JAMES E. HEUBI, BRUCE W. HOLLIS, AND REGINALD C. TSANG \\ Division of Gastroenterology and Nutrition, Children's Hospital Research Foundation, Cincinnati, Ohio 45229 \\ [E.A.A., J.E.H.]; Department of Pediatrics, Medical University of South Carolina, Charleston, South Carolina \\ 29425 [B.W.H.]; and Department of Pediatrics, University of Cincinnati, Cincinnati, Ohio 45267 [R.C.T.]
}

\begin{abstract}
Rickets and osteopenia, common problems in chronic childhood cholestasis, have been attributed to vitamin $\mathrm{D}$ malabsorption leading to reduced serum levels of $25(\mathrm{OH})$-vitamin D. $d$ - $\alpha$-Tocopheryl polyethylene glycol1000 succinate (TPGS), a water-soluble form of vitamin $E$, forms micelles at low concentration. We evaluated the potential role of TPGS in enhancing vitamin $D$ absorption in eight children (aged 5 mo to $19 \mathrm{y}$ ) with severe chronic cholestasis (three extrahepatic biliary atresia, three nonsyndromic intrahepatic cholestasis, and two Alagille syndrome). To evaluate vitamin $D$ absorption, the subjects received vitamin $D_{3} 1000 \mathrm{IU} / \mathrm{kg}$ (maximum dose of 50000 IU); they then received the same dose of vitamin $D_{3}$ mixed with TPGS ( $25 \mathrm{IU} / \mathrm{kg})$. Serial serum vitamin $D_{3}$ levels and areas under the curve were measured. All patients had enhanced absorption of vitamin D when it was administered in a mixture with TPGS. Mean area under the curve for serum vitamin $D_{3}$ was $403.0 \pm 83.1 \mathrm{nmol} \times \mathrm{h} / \mathrm{L}(155.6 \pm$ $32.1 \mathrm{ng} \times \mathrm{h} / \mathrm{mL}$ ), with a mean rise above baseline of 13.5 $\pm 1.8 \mathrm{nmol} / \mathrm{L}(5.2 \pm 0.7 \mathrm{ng} / \mathrm{mL})$ with vitamin $\mathrm{D} / \mathrm{TPGS}$ compared with no rise when vitamin $D$ was given alone (both $p<0.001$ ). Seven patients have been followed for at least 3 mo while receiving the vitamin D/TPGS combination. Those with initially low serum $25(\mathrm{OH})$-vitamin D levels $(<37.5 \mathrm{nmol} / \mathrm{L}$ or $15 \mathrm{ng} / \mathrm{mL}$ ) had normalization (range 37.5-146 $\mathrm{nmol} / \mathrm{L}$ ) within $1 \mathrm{mo}$, whereas those with initially normal levels remained normal. While the patients were receiving vitamin D/TPGS, serum vitamin $E$ to total lipid ratio either normalized or remained normal. In conclusion, 1) TPGS enhances vitamin $D$ absorption in infants and children with severe chronic cholestasis and 2) the enhanced absorption of both vitamins is sufficient to normalize or maintain adequate levels of serum $25(\mathrm{OH})$ vitamin $\mathrm{D}$ and vitamin $\mathrm{E}$ to total lipid ratio. (Pediatr Res 31: 146-150, 1992)
\end{abstract}

\section{Abbreviations}

25(OH)D, 25-hydroxy-vitamin D

TPGS, $d$ - $\alpha$-tocopheryl polyethylene glycol-1000 succinate

Received April 15, 1991; accepted September 20, 1991.

Correspondence: Eric A. Argao, M.D., Division of Gastroenterology and Nutrition, ASB-4, Children's Hospital Medical Center, Elland and Bethesda Avenues, Cincinnati, $\mathrm{OH} 45229$.

Reprint requests: James E. Heubi, M.D., Division of Gastroenterology and Nutrition, ASB-4, Children's Hospital Medical Center, Elland and Bethesda Avenues, Cincinnati, OH 45229.

Supported by funds from the Children's Hospital Research Foundation.
Bone disease (rickets and osteopenia) is a common complication of chronic childhood cholestatic liver disease (1-3). Affected children have reduced levels of serum $25(\mathrm{OH}) \mathrm{D}$ secondary to poor intestinal absorption of fat-soluble vitamins because of reduced intraluminal bile acids, decreased sun exposure compounded by their chronic illness and multiple hospitalizations, and impaired hepatic hydroxylation of cholecalciferol to $25-\mathrm{OH}-$ cholecalciferol in end-stage liver disease $(1,4-7)$. Despite the ingestion of massive doses of oral vitamin $\mathrm{D}_{2}$ or $\mathrm{D}_{3}$, metabolic bone disease may still develop. Various alternative modalities of therapy, including parenteral cholecalciferol and oral calcifediol and calcitriol, have been used in an attempt to normalize serum $25(\mathrm{OH}) \mathrm{D}$ levels $(3-5,8-10)$.

Similar to vitamin D, orally administered vitamin $\mathrm{E}$ is dependent upon bile salts for solubilization and facilitation of absorption. TPGS, a water-solubilized form of vitamin $\mathrm{E}$, forms micelles at low concentrations (11). As early as 1970, evidence was available suggesting that vitamin $\mathrm{E}$ as TPGS was absorbed in infants with extrahepatic biliary atresia and cystic fibrosis (12). More recently, TPGS was shown to be an effective form of therapy for vitamin $\mathrm{E}$ deficiency in children with severe chronic cholestasis (13). The present study was designed to evaluate the potential role of TPGS in enhancing the absorption of vitamin $\mathrm{D}_{3}$ from the gastrointestinal tract in infants and children with chronic cholestatic disease.

\section{MATERIALS AND METHODS}

Eight patients (one male, seven females), aged 5 mo to $19 \mathrm{y}$, with chronic cholestatic liver disease were enrolled. Three had extrahepatic biliary atresia, two had Alagille syndrome, and three had nonsyndromic intrahepatic cholestasis.

Of seven patients available for follow-up after the tolerance test, while receiving the vitamin D/TPGS combination, five were on ursodeoxycholic acid $(15 \mathrm{mg} / \mathrm{kg} / \mathrm{d})$. Four of these five had been on ursodeoxycholic acid for a mean duration of 6 mo (range 3-13 mo) before our study, whereas the remaining patient was started on ursodeoxycholic acid right after the tolerance tests for vitamin D (alone) and vitamin D/TPGS were performed. Four patients were receiving phenobarbital $(2-6 \mathrm{mg} / \mathrm{kg} / \mathrm{d})$ before and during vitamin D/TPGS therapy.

Baseline evaluation. All patients were admitted to the Clinical Research Center and fasting blood samples were drawn for liver profile (aspartate aminotransferase, alanine aminotransferase, alkaline phosphatase, total protein, albumin, prothrombin time, cholesterol), calcium, magnesium, phosphorus, electrolytes, urea nitrogen, creatinine, and osmolarity. All were measured by standard chemistry methods used in the clinical laboratories of Children's Hospital Medical Center. Blood was similarly taken for 
determination of serum vitamin $E$ level and total lipid and serum vitamin $\mathrm{D}$ and vitamin $\mathrm{D}$ metabolites. Plain $\mathrm{x}$-rays of the wrist and/or knee and bone mineral content measurements were done.

Vitamin $D$ absorption. After an overnight fast, vitamin $\mathrm{D}_{3}$ (Duphar Nutrition, Inc., Waukegan, IL) $1000 \mathrm{IU} / \mathrm{kg}$ (maximum dose of $50000 \mathrm{IU})$ was administered orally. Regular diet was resumed $2 \mathrm{~h}$ later. Serum vitamin $\mathrm{D}_{3}$ levels were determined serially at $0,4,8,12$, and $24 \mathrm{~h}$ as outlined by Lo et al. (14). On the next day, after another overnight fast, a mixture of the same dose of vitamin $\mathrm{D}_{3}$ and TPGS (Liqui-E; Twin Laboratories, Ronkonkoma, NY) $25 \mathrm{IU} / \mathrm{kg}$ was administered orally. Regular diet was again resumed $2 \mathrm{~h}$ after dosing. Serial measurements of serum vitamin $\mathrm{D}_{3}$ and vitamin $E$ levels were obtained at $0,4,8$, 12,24 , and $48 \mathrm{~h}$.

Analytical methods. Serum vitamin D and its metabolites were measured using methods of solid-phase extraction from the serum. Levels were determined by direct UV absorption after separation by HPLC (15). The normal range for total serum $25(\mathrm{OH}) \mathrm{D}$ for adults using this technique is $37.5-125 \mathrm{nmol} / \mathrm{L}$ (15-50 ng/mL); the normal range for serum 1,25-dihydroxyvitamin D is $60-120 \mathrm{pmol} / \mathrm{L}(25-50 \mathrm{pg} / \mathrm{mL})$.

Serum vitamin E levels were determined by the fluorometric technique and serum total lipid was measured by colorimetry (16). The ratio of vitamin $E$ to total serum lipid was calculated because vitamin $\mathrm{E}$ is known to partition from red cell membranes into serum containing elevated lipid concentrations (17-20). Normal values for serum vitamin $\mathrm{E}$ to total lipid ratio for patients less than $12 \mathrm{y}$ old is $0.6 \mathrm{mg} / \mathrm{g}$ and for older children, $0.8 \mathrm{mg} / \mathrm{g}$ $(18,19)$.

Plain $x$-rays of the wrists and/or knees were taken. Bone mineral content was measured by direct single-beam photon absorptiometry of the distal one third of the left radius using a Lunar Bone Mineral (Lunar Corp., Madison, WI) analyzer designed for use in infants and children. A narrow band of low energy radiation $\left({ }^{125} \mathrm{I}\right)$ and a collimated scintillation detector were moved across the forearm. This method accurately indicates the ash weight of bone. Comparisons were made with age- and sex-specific norms (21).

Follow-up. The patients were discharged while receiving vitamin $\mathrm{D}_{3} 1000 \mathrm{IU} / \mathrm{kg}$ mixed with TPGS $25 \mathrm{IU} / \mathrm{kg}$ (the same dose used for the tolerance test), given on a once-daily basis. They were followed monthly for the first 3 mo and thereafter every 3 mo, with monitoring of levels of vitamin $\mathrm{D}$ and its metabolites, serum levels of vitamin $\mathrm{E}$ and total lipid, calcium, magnesium, and phosphorus. Bone mineral content was determined every 6 mo, at which time the wrist and knee $x$-ray was repeated if a patient was found to have rickets at the start of the study.

Statistical analysis. Results are shown as mean \pm SEM. Statistical analyses included two-tailed $t$ test and analysis of variance. Areas under the curve were calculated using the linear/logarithmic trapezoidal rule and were computed using PKCALC (22).

This project was approved by the Institutional Review Board involving Human Subjects of the Children's Hospital Medical Center in Cincinnati. Written informed consent was obtained from parents or guardians and from patients when they were more than 11 y old

\section{RESULTS}

The clinical profile of the study subjects is shown in Table 1. All patients were cholestatic with direct bilirubin from 1.0-27.2 $\mu \mathrm{mol} / \mathrm{L}$. The patient with a conjugated bilirubin value of 1.0 $\mu \mathrm{mol} / \mathrm{L}$ had persistently high serum levels of cholylglycine (125$200 \mu \mathrm{mol} / \mathrm{L}$ ). Alkaline phosphatase values were all elevated. Serum bilirubin and alkaline phosphatase did not change significantly during the follow-up period, suggesting no significant alteration in the degree of cholestasis in our patients (no difference was noted even in those taking phenobarbital and/or ursodeoxycholic acid). All patients had prothrombin times $<2.8 \mathrm{~s}$ above control. Five patients had reduced serum albumin; none had ascites. Serum calcium levels were normal in all but one patient $(2.0 \mathrm{mmol} / \mathrm{L})$, who was also hypoalbuminemic (to 32 $\mu \mathrm{mol} / \mathrm{L})$.

Vitamin D was not detectable in the serum of any of the patients at baseline. Four were taking oral vitamin $\mathrm{D}$, three were receiving $25(\mathrm{OH}) \mathrm{D}$ (calcifediol), and one was receiving 1,25 dihydroxyvitamin D (calcitriol). Serum 25(OH)D levels were low $(<37.5 \mathrm{nmol} / \mathrm{L}$ or $15 \mathrm{ng} / \mathrm{mL}$ ) in five of the eight patients (Table 2 ). Of the five, three were receiving vitamin $\mathrm{D}$ doses of $400-850$ $\mathrm{IU} / \mathrm{kg}$, one was receiving calcifediol (with a serum level of 21.2 $\mathrm{nmol} / \mathrm{L}$ or $8.5 \mathrm{ng} / \mathrm{mL}$ ), and one was receiving calcitriol. Among the three patients with normal $25(\mathrm{OH}) \mathrm{D}$ levels, two were receiving calcifediol and one was receiving vitamin $D_{3} 97 \mathrm{rU} / \mathrm{kg}$.

Of the eight patients in the study, four were receiving TPGS and had serum vitamin E/total lipid from 0.73 to $1.4 \mathrm{mg} / \mathrm{g}$ (Table 3). Of the remaining four subjects, three were being treated with Aquasol E (Rorer Pharmaceutical, Fort Washington, PA) and all had extremely low ratios $(0.15-0.21 \mathrm{mg} / \mathrm{g})$. One patient, who had a low serum $25(\mathrm{OH}) \mathrm{D}$ level while taking calcifediol, had a low vitamin $E$ to total lipid ratio $(0.16 \mathrm{mg} / \mathrm{g})$ while taking TPGS.

Radiographically, seven of the eight patients were osteopenic, although none had changes that were unequivocally consistent with rickets. One patient had a normal bone mineral content, whereas the rest had bone mineral content from 1 to 5 SD below the age-specific norms, with values ranging from 32 to $64 \%$ of normal (Table 2). Four of the five subjects with low serum $25(\mathrm{OH}) \mathrm{D}$ levels were also osteopenic.

Absorption studies. All patients have previously been shown to be unable to absorb vitamin $\mathrm{D}_{3}$ by oral vitamin $\mathrm{D}$ tolerance test with a dose of $1000 \mathrm{IU} / \mathrm{kg}$. Administration of $1000 \mathrm{IU} / \mathrm{kg}$ of vitamin $\mathrm{D}_{3}$ mixed with TPGS $25 \mathrm{IU} / \mathrm{kg}$ resulted in a mean peak rise of serum vitamin $\mathrm{D}_{3}$ level from baseline of $13.5 \pm 1.8$ $\mathrm{nmol} / \mathrm{L}(5.2 \pm 0.7 \mathrm{ng} / \mathrm{mL})$, with a range of $6.0-19.4 \mathrm{nmol} / \mathrm{L}$ $(2.3-7.5 \mathrm{ng} / \mathrm{mL})$. The rise above baseline with the vitamin $\mathrm{D} /$ TPGS mixture was significantly different $(p<0.001)$ from the rise noted when vitamin $D_{3}$ was administered alone. Peak concentrations were reached at $4 \mathrm{~h}$ in one subject, at $8 \mathrm{~h}$ in two, at $12 \mathrm{~h}$ in four, and at $24 \mathrm{~h}$ in one. The mean vitamin $\mathrm{D}_{3}$ level was $4.7 \pm 1.3 \mathrm{nmol} / \mathrm{L}(1.8 \pm 0.5 \mathrm{ng} / \mathrm{mL})$ at $4 \mathrm{~h}, 10.9 \pm 1.3 \mathrm{nmol} / \mathrm{L}$ $(4.2 \pm 0.5 \mathrm{ng} / \mathrm{mL})$ at $8 \mathrm{~h}, 12.4 \pm 2.0 \mathrm{nmol} / \mathrm{L}(4.8 \pm 0.8 \mathrm{ng} / \mathrm{mL})$ at $12 \mathrm{~h}, 10.4 \pm 2.0 \mathrm{nmol} / \mathrm{L}(4.0 \pm 0.8 \mathrm{ng} / \mathrm{mL})$ at $24 \mathrm{~h}$, and 5.2 $\pm 2.0 \mathrm{nmol} / \mathrm{L}(2.0 \pm 0.8 \mathrm{ng} / \mathrm{mL})$ at $48 \mathrm{~h}$ (Fig. 1). The mean area under the curve of serum vitamin $\mathrm{D}_{3}$ was $403.0 \pm 83.1 \mathrm{nmol} \times$ $\mathrm{h} / \mathrm{L}$ after the patients received the vitamin D/TPGS mixture, which was significantly different from 0 when vitamin $D_{3}$ was administered alone $(p<0.001)$. We have previously shown that administration of $1000 \mathrm{IU} / \mathrm{kg}$ of vitamin D to noncholestatic controls resulted in a peak rise from baseline of serum vitamin $\mathrm{D}$ of $158.0 \pm 25.4 \mathrm{nmol} / \mathrm{L}$ or $61.0 \pm 9.8 \mathrm{ng} / \mathrm{mL}$ (range $103.6-$ $253.3 \mathrm{nmol} / \mathrm{L}$ or $40.0-97.8 \mathrm{ng} / \mathrm{mL}$ ) at $8-12 \mathrm{~h}$. In one control subject, the peak was reached at $4 \mathrm{~h}$. The area under the curve for the vitamin $D$ tolerance test was $4921 \pm 474 \mathrm{nmol} \times \mathrm{h} / \mathrm{L}$ $(1900 \pm 183 \mathrm{ng} \times \mathrm{h} / \mathrm{mL})(10)$.

$25(O H) D$. One patient underwent orthotopic liver transplantation $2 \mathrm{wk}$ after the absorption study. Seven patients have been followed for at least 3 mo while receiving the vitamin D/TPGS combination. Five of these seven patients, who initially had serum $25(\mathrm{OH}) \mathrm{D}$ levels below $37.5 \mathrm{nmol} / \mathrm{L}(15 \mathrm{ng} / \mathrm{mL})$, were found to have normalized their levels to a range of 37.5-146 $\mathrm{nmol} / \mathrm{L}(15-58 \mathrm{ng} / \mathrm{mL})$ by 1 mo (Table 4$)$. The other two patients, both of whom were taking calcifediol and had normal serum $25(\mathrm{OH}) \mathrm{D}$, maintained normal levels $(70-100 \mathrm{nmol} / \mathrm{L})$ after 6 mo of therapy. Six patients available for follow-up have maintained normal serum 25(OH)D concentrations (range 65$134 \mathrm{nmol} / \mathrm{L}$ ) for at least $6 \mathrm{mo}$. None of the patients required a decrease in vitamin $\mathrm{D}$ dose during the course of therapy with vitamin $\mathrm{D}_{3} /$ TPGS because of high levels of serum $25(\mathrm{OH}) \mathrm{D}$.

Serum vitamin E/total lipid. On follow-up of the three patients previously taking Aquasol E with initial ratios of $0.11-0.30 \mathrm{mg} /$ 
Table 1. Patient profile*

\begin{tabular}{|c|c|c|c|c|c|c|c|c|}
\hline Patient & $\begin{array}{c}\text { Age } \\
(\mathrm{y})\end{array}$ & Sex & Diagnosis & $\begin{array}{c}\text { Direct } \\
\text { bilirubin } \\
(\mu \mathrm{mol} / \\
\mathrm{L}) \\
\end{array}$ & $\begin{array}{c}\text { Alkaline } \\
\text { phosphatase } \\
\text { (katal/L) }\end{array}$ & $\begin{array}{c}\text { Calcium } \\
(\mathrm{mmol} / \mathrm{L})\end{array}$ & $\begin{array}{l}\text { Albumin } \\
(\mu \mathrm{mol} / \mathrm{L}) \\
\end{array}$ & $\begin{array}{l}\text { Prothrombin } \\
\text { time/control } \\
\text { (s) }\end{array}$ \\
\hline 1 & 8.5 & $F$ & Alagille & 7.4 & $12.9 \times 10^{-6}$ & 2.4 & 60 & $14.7 / 12.9$ \\
\hline $2 \dagger$ & 1.2 & $\mathrm{~F}$ & EHBA & 19.0 & $26.3 \times 10^{-6}$ & 2.5 & 47 & $11.0 / 13.0$ \\
\hline 3 & 3.5 & $\mathrm{~F}$ & Alagille & 27.2 & $13.5 \times 10^{-6}$ & 2.2 & 44 & $11.9 / 12.9$ \\
\hline 4 & 1.7 & $\mathrm{~F}$ & NSIHC & 3.3 & $6.2 \times 10^{-6}$ & 2.4 & 57 & $11.6 / 12.9$ \\
\hline 5 & 19 & $M$ & NSIHC & 1.0 & $3.8 \times 10^{-6}$ & 2.4 & 66 & $13.9 / 13.2$ \\
\hline $6 \ddagger$ & 0.4 & F & EHBA & 3.8 & $10.5 \times 10^{-6}$ & 2.2 & 39 & $15.4 / 12.9$ \\
\hline $7 \S$ & 9.5 & $\mathrm{~F}$ & NSIHC & 21.8 & $6.8 \times 10^{-6}$ & 2.0 & 32 & $15.8 / 13.0$ \\
\hline $8 \dagger$ & 0.8 & $\mathrm{~F}$ & EHBA & 20.6 & $13.5 \times 10^{-6}$ & 2.4 & 39 & $12.0 / 13.0$ \\
\hline
\end{tabular}

${ }^{*}$ Reference values: Direct bilirubin: $<0.34 \mu \mathrm{mol} / \mathrm{L}$. Alkaline phosphatase: $2.3-3.9 \times 10^{-6} \mathrm{~kat} / \mathrm{L}, 0-2 \mathrm{y} ; 3.9-12.3 \times 10^{-6} \mathrm{~kat} / \mathrm{L}, 2-17 \mathrm{y} ; 0.5-2.0$ $\times 10^{-6} \mathrm{~kat} / \mathrm{L}$, adult. Calcium: $2.1-2.7 \mathrm{mmol} / \mathrm{L}$. Albumin: $51-75 \mu \mathrm{mol} / \mathrm{L}$. EHBA, extrahepatic biliary atresia; NSIHC, nonsyndromic intrahepatic cholestasis.

$\uparrow$ Transplanted after 6 mo.

$\ddagger$ Transplanted after 4 mo.

$\S$ Transplanted after 2 wk.

Table 2. Vitamin D profile

\begin{tabular}{|c|c|c|c|c|c|}
\hline \multirow[b]{2}{*}{ Patient } & \multirow[b]{2}{*}{ Vitamin D form (dosage) } & \multirow{2}{*}{$\begin{array}{c}\text { Serum 25(OH)D } \\
(\mathrm{nmol} / \mathrm{L})^{*}\end{array}$} & \multicolumn{2}{|c|}{ Bone mineral content } & \multirow[b]{2}{*}{ Rickets } \\
\hline & & & $\mathrm{SD}$ below & $\%$ of normal $\uparrow$ & \\
\hline 1 & $\mathrm{D}_{2}(400 \mathrm{IU} / \mathrm{kg})$ & 28.7 & $2-4$ & 64 & \pm \\
\hline 2 & $25(\mathrm{OH}) \mathrm{D}(2 \mu \mathrm{g} / \mathrm{kg})$ & 185.0 & $4-5$ & 38 & - \\
\hline 3 & $25(\mathrm{OH}) \mathrm{D}(3.8 \mu \mathrm{g} / \mathrm{kg})$ & 21.2 & $2-3$ & 42 & \pm \\
\hline 4 & $1,25 \mathrm{di}(\mathrm{OH}) \mathrm{D}(0.05 \mu \mathrm{g} / \mathrm{kg})$ & 22.5 & Normal & Normal & - \\
\hline 5 & $25(\mathrm{OH}) \mathrm{D}(1 \mu \mathrm{g} / \mathrm{kg})$ & 166.5 & $2-4$ & 63 & - \\
\hline 6 & $\mathrm{D}_{3}(470 \mathrm{IU} / \mathrm{kg})$ & 5.0 & $1-2$ & 32 & - \\
\hline 7 & $\mathrm{D}_{3}(97 \mathrm{IU} / \mathrm{kg})$ & 41.7 & 3 & 52 & - \\
\hline 8 & $\mathrm{D}_{2}(850 \mathrm{IU} / \mathrm{kg})$ & 19.5 & $2-3$ & 42 & \pm \\
\hline
\end{tabular}

* Conversion factor for serum $25(\mathrm{OH}) \mathrm{D}$ level: $\mathrm{ng} / \mathrm{mL}$ (conventional unit) $\times 2.496=\mathrm{nmol} / \mathrm{L}$ (SI unit).

$\dagger$ Values compared with age-specific norms.

Table 3. Vitamin E profile

\begin{tabular}{clc}
\hline Patient & \multicolumn{1}{c}{$\begin{array}{c}\text { Vitamin E form } \\
\text { (dosage) }\end{array}$} & $\begin{array}{c}\text { Serum vitamin E/total } \\
\text { lipid }(\mathrm{mg} / \mathrm{g})\end{array}$ \\
\hline 1 & TPGS (16 IU $/ \mathrm{kg})$ & 0.79 \\
2 & TPGS (20 IU $/ \mathrm{kg})$ & 0.73 \\
3 & TPGS (45 IU $/ \mathrm{kg})$ & 0.16 \\
4 & Aquasol E (48 IU $/ \mathrm{kg})$ & 0.15 \\
5 & TPGS $(32 \mathrm{IU} / \mathrm{kg})$ & 0.87 \\
6 & Aquasol E $(75 \mathrm{IU} / \mathrm{kg})$ & 0.30 \\
7 & TPGS $(15 \mathrm{IU} / \mathrm{kg})$ & 1.40 \\
8 & Aquasol E $(69 \mathrm{IU} / \mathrm{kg})$ & 0.11 \\
\hline
\end{tabular}

$\mathrm{g}$, serum vitamin $\mathrm{E} /$ total lipid values were found to have normalized to $0.6-1.7 \mathrm{mg} / \mathrm{g}$ at $3 \mathrm{mo}$ (Table 4$)$. Three patients previously receiving TPGS with normal serum vitamin $E$ to total lipid ratios on admission into the study maintained normal ratios. The patient who started with a low ratio $(0.16 \mathrm{mg} / \mathrm{g})$ despite previous therapy with TPGS subsequently normalized her ratio (to $0.83 \mathrm{mg} / \mathrm{g}$ ) at $3 \mathrm{mo}$. The initially low levels of serum $25(\mathrm{OH}) \mathrm{D}$ and vitamin $\mathrm{E}$ to total lipid ratio in this patient were attributed to poor compliance (see Table 4, patient 3). Six patients have maintained normal serum vitamin $\mathrm{E} /$ total lipid for at least 6 mo.

Bone mineral content. We repeated the bone mineral content determination on six patients at $6 \mathrm{mo}$ and on two patients again at $12 \mathrm{mo}$. None of them had deterioration (i.e. decrease in percentage of normal) in bone density while receiving therapy compared with age-matched control subjects.

\section{DISCUSSION}

The aqueous environment of the intestinal lumen poses a major obstacle to the absorption of fat and fat-soluble vitamins.
Formation of mixed micelles is accomplished by interaction of bile acids with lipids, including fat-soluble vitamins. This step is a prerequisite for solubilization of lipophilic substances in an aqueous phase, from which they can be absorbed by enterocytes (23). When micelles carry the lipid-soluble substances toward the absorptive microvillus cell membrane, their collision with the cell membrane results in partitioning of fat-soluble vitamins (but not bile salts) into the monomeric phase, allowing penetration of the lipid cell membrane $(24,25)$.

Vitamin $\mathrm{D}$ is absorbed by enterocytes by a nonsaturable, passive bile salt-dependent diffusion process $(26-29)$. Studies using serial serum measurements of vitamin D after an oral load, as performed in the present study, have shown that normal adults and children have a predictable rise in serum vitamin $\mathrm{D}$, whereas adults and children with malabsorption syndromes, including cholestatic diseases, have reduced postdose serum rises $(6,10$, 14). In patients with chronic cholestatic liver disease, intraluminal bile acid deficiency results in malabsorption of fat and fatsoluble substances, including vitamin D. Malabsorption is the primary cause of reduced serum $25(\mathrm{OH}) \mathrm{D}$ in adults with primary biliary cirrhosis (30-32) and in children with chronic cholestasis (6). In comparing two groups of patients with extrahepatic biliary atresia, we showed that good postoperative bile flow was associated with normal vitamin $\mathrm{D}$ absorption and serum $25(\mathrm{OH}) \mathrm{D}$ levels (10). Only one of six patients studied with good postoperative bile flow had a baseline serum $25(\mathrm{OH}) \mathrm{D}$ below $37.5 \mathrm{nmol} /$ $\mathrm{L}(15 \mathrm{ng} / \mathrm{mL})$. These data suggest that significant malabsorption of vitamin D accompanies cholestatic liver disease in most, but not all, pediatric patients. In the present study, all eight patients with severe cholestasis had no measurable rise in serum vitamin $\mathrm{D}$ after an oral challenge, with accompanying low levels of serum $25(\mathrm{OH}) \mathrm{D}$ and varying degrees of bone undermineralization. It is important to remember, however, that tolerance tests, as carried 

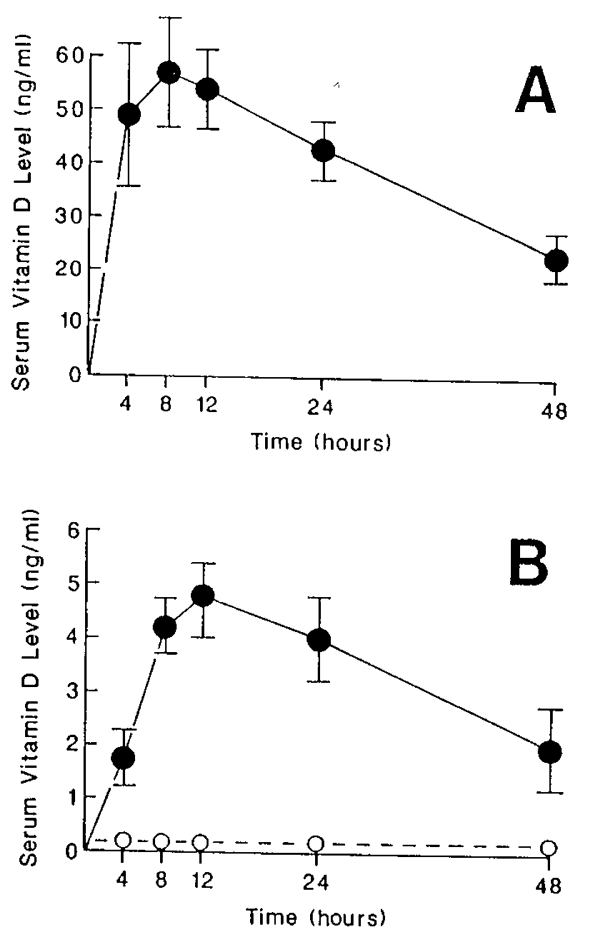

Fig. 1. Vitamin D absorption studies. Serum vitamin D concentrations (mean \pm SEM) after an oral load of vitamin D $1000 \mathrm{IU} / \mathrm{kg}$ in five control patients $(A)$ and after a test dose of vitamin $\mathrm{D} 1000 \mathrm{IU} / \mathrm{kg}$ mixed with TPGS $25 \mathrm{IU} / \mathrm{kg}$ in eight infants and children with chronic cholestasis (B). Broken line in $B$ shows the inability of these eight severely cholestatic patients to absorb vitamin $\mathrm{D}$ when it was administered alone. Note difference in scale between the two graphs; peak rise from baseline is 57 $\mathrm{ng} / \mathrm{mL}(147.6 \mathrm{nmol} / \mathrm{L})$ in $A$, as opposed to $4.8 \mathrm{ng} / \mathrm{mL}(12.4 \mathrm{nmol} / \mathrm{L})$ in $B$. Conversion factor for serum vitamin $\mathrm{D}$ level: $\mathrm{ng} / \mathrm{mL}$ (conventional unit) $\times 2.59=\mathrm{nmol} / \mathrm{L}$ (SI unit).

out in our study, are a mere reflection of absorption and will therefore be limited by their inability to take into consideration factors beyond their scope, such as tissue distribution and metabolism.

Like vitamin $\mathrm{D}$, vitamin $\mathrm{E}$ absorption is dependent upon intraluminal bile acid concentrations exceeding the critical micellar concentration (33). Solubilization of tocopherol by bile salts is a function of micellar size and the less polar bile salts form micelles with vitamin E more easily (34). Recent studies have led to the recognition of a novel form of vitamin $E$ with aqueous solubility. TPGS can form micelles (with a critical micellar concentration of $0.04-0.06 \mathrm{mM}$ ), which facilitate tocopherol delivery to the intestinal mucosal cell $(11,13)$. These critical micellar concentrations are well below those found in the commercially available form, Liqui-E. Results of studies on the role of TPGS in the treatment of vitamin E deficiency in children with chronic cholestasis have concluded that oral TPGS is safe and efficacious for prolonged usage, especially in the low doses used (13). Experience on its use now includes about 65 patients who have been followed for up to 4-5 y (RJ Sokol, personal communication).

In the present study, we have shown that TPGS, an agent that solubilizes vitamin D by incorporation into micelles, enhances its absorption in the face of intraluminal bile acid deficiency. Although vitamin D absorption was not normalized by solubilizing with TPGS, it was enhanced sufficiently to result in a measurable postdose rise in serum vitamin $\mathrm{D}$ level and normalization of serum $25(\mathrm{OH}) \mathrm{D}$ concentrations within a month.

Numerous investigations have been conducted in search of better therapy for vitamin $\mathrm{D}$ deficiency states in infants and children with chronic cholestasis. Several reports have claimed success in preventing or treating bone disease in cholestatic patients, in whom oral vitamin $\mathrm{D}$ was ineffective, with the use of oral $25(\mathrm{OH})$-vitamin $\mathrm{D}(8,9,35)$. We have previously recommended the use of $25(\mathrm{OH}) \mathrm{D}$ to prevent bone disease in patients with "failed" portoenterostomy while awaiting orthotopic liver transplantation (10). These patients face the additional risk of decreased formation of skin cholecalciferol because of lack of sun exposure as a result of recurrent hospital admissions for biliary tract infections, sepsis, and/or nutritional complications, all occurring at a crucial time. Therapy with calcifediol may result in a normal serum level of $25(\mathrm{OH}) \mathrm{D}$, but in the case of two patients in our study, was not enough to prevent osteopenia. Furthermore, its use is limited by its cost and dosage preparation (20- and 50- $\mu$ g capsules). Roberts et al. (3) reported improved bone density in eight of 12 children with cholestatic liver disease when treated with $0.05-0.1 \mu \mathrm{g} / \mathrm{kg} / \mathrm{d}$ of calcitriol. Problems with dosage preparation (0.25- and $0.5-\mu$ g capsules), extremely high cost, and potential toxicity compromise its utility. The availability of an alternate form of therapy, such as vitamin D/TPGS combination, will reduce patients' expenses and allow the use of a liquid compound that can be dispensed and modified from patient to patient. We have shown that changing from calcifediol to this form of vitamin $\mathrm{D}$ administration in three subjects allowed them to maintain serum $25(\mathrm{OH}) \mathrm{D}$ levels within the normal range and normalize serum $25(\mathrm{OH}) \mathrm{D}$ levels in those patients who previously had low levels while receiving vitamin $\mathrm{D}$ alone. Follow-up testing of six patients on vitamin D/TPGS therapy did not reveal any fluctuations in serum $25(\mathrm{OH}) \mathrm{D}$ level that might lead us to consider seasonal variation as a factor behind this improvement $(7,36)$.

Based upon our studies, we believe that TPGS forms micellar particles with vitamin $\mathrm{D}$. The solubilized vitamins traverse the unstirred water layer and are released into monomeric phase as the micellar particle comes in contact with the absorbing enterocyte, thereby facilitating their absorption. In the presence of intraluminal bile acid deficiency, we have found that TPGS may play an important role in enhancing the absorption of vitamin $\mathrm{D}$ and other fat-soluble vitamins and compounds. Studies have already suggested its utility in enhancing the absorption of cyclo-

Table 4. Follow-up serum $25(O H) D$ and vitamin E/lipid levels at baseline and on therapy with vitamin D/TPGS*

\begin{tabular}{|c|c|c|c|c|c|c|c|c|c|c|c|c|c|c|}
\hline \multirow[b]{2}{*}{ Patient } & \multicolumn{7}{|c|}{ Serum $25(\mathrm{OH}) \mathrm{D}(\mathrm{nmol} / \mathrm{L})$} & \multicolumn{7}{|c|}{ Serum vitamin E/lipid $(\mathrm{mg} / \mathrm{g})$} \\
\hline & $0 \mathrm{mo}$ & $1 \mathrm{mo}$ & $2 \mathrm{mo}$ & $3 \mathrm{mo}$ & $6 \mathrm{mo}$ & $9 \mathrm{mo}$ & $12 \mathrm{mo}$ & $0 \mathrm{mo}$ & $1 \mathrm{mo}$ & $2 \mathrm{mo}$ & $3 \mathrm{mo}$ & $6 \mathrm{mo}$ & $9 \mathrm{mo}$ & $12 \mathrm{mo}$ \\
\hline 1 & 28.7 & 58.2 & 88.1 & 149.8 & 111.8 & 112.6 & 93.6 & 0.79 & 0.73 & 0.98 & 1.03 & 0.54 & 1.08 & 0.79 \\
\hline $2 \dagger$ & 185.0 & 114.8 & ND & 99.8 & 70.4 & & & 0.73 & 0.42 & ND & 0.63 & 0.84 & & \\
\hline 3 & 21.2 & $\mathrm{ND}$ & 77.4 & 128.5 & 121.8 & ND & 65.6 & 0.16 & ND & 0.49 & 0.83 & 0.56 & ND & 0.54 \\
\hline 4 & 22.5 & 146.0 & 118.3 & 99.1 & 133.8 & 105.3 & 105.8 & 0.15 & 1.66 & 1.43 & 1.69 & 1.24 & 1.26 & 1.24 \\
\hline 5 & 166.5 & 103.3 & ND & 99.8 & 99.8 & 94.1 & 96.8 & 0.87 & 1.0 & ND & 0.75 & 1.45 & 0.60 & 0.68 \\
\hline $6 \ddagger$ & 5.0 & 37.5 & 33.9 & 103.3 & & & & 0.30 & 1.77 & 1.20 & 1.61 & & & \\
\hline $8 \dagger$ & 19.5 & 67.4 & 44.7 & 59.9 & 93.6 & & & 0.11 & 0.70 & 0.45 & 0.67 & 0.71 & & \\
\hline
\end{tabular}

* See Table 2 for conversion of serum $25(\mathrm{OH}) \mathrm{D}$ level from conventional to SI unit. ND, not determined.

$\dagger$ Underwent liver transplantation after 6 mo.

$\ddagger$ Underwent liver transplantation after 4 mo. 
sporin A, a highly lipophilic compound, in the presence of cholestasis or with a long Roux-En-Y loop after liver transplantation (37).

Acknowledgments. The authors thank the patients and their families for participating in this study; Andrea Smith, Cindy Seibert, Karen Schulte, Pat Fant, Joyce Slusher, Gail Enright, and the CRC Nurses for their invaluable assistance; and William F. Balistreri for his advice.

\section{REFERENCES}

1. Kobayashi A, Kawai S, Utsunomiya T, Ohbe Y 1974 Bone disease in infants and children with hepatobiliary disease. Arch Dis Child 49:641-646

2. Glasgow JFT, Thomas PA 1976 The osteodystrophy of prolonged obstructive liver disease in childhood. Acta Paediatr Scand 65:57-64

3. Roberts CC, Book LS, Chan GM, Matlak ME 1981 Rickets in children with cholestatic liver disease: evaluation and treatment. Pediatr Res 15:544(abstr)

4. Seino Y, Shimotsuji T, Kai H, Ikehara C, Yabuuchi H 1978 The plasma levels of 25 -hydroxyvitamin $\mathrm{D}$ in patients with various liver diseases and the response of 25-hydroxy-vitamin D to vitamin D treatment. Acta Paediatr Scand 67:39-42

5. Kooh SW, Jones G, Reilly BJ, Fraser D 1970 Pathogenesis of rickets in chronic hepatobiliary disease in children. $J$ Pediatr 94:870-874

6. Heubi JE, Hollis BW, Specker B, Tsang RC 1989 Bone disease in chronic childhood cholestasis. I. Vitamin D absorption and metabolism. Hepatology 9:258-264

7. Specker BL, Tsang RC 1987 Cyclical serum 25-hydroxyvitamin D concentrations paralleling sunshine exposure in exclusively breast-fed infants. J Pediatr 110:744-747

8. Kimura S, Seino Y, Harada T, Nose O, Yamaoka K, Shimizu K, Tanaka H, Yabuuchi H, Fukui Y, Kamata S, Okada A 1988 Vitamin D metabolism in biliary atresia: intestinal absorptions of 25 -hydroxyvitamin $D_{3}$ and $1,25-$ dihydroxyvitamin $\mathrm{D}_{3}$. J Pediatr Gastroenterol Nutr 7:341-346

9. Daum F, Rosen JF, Roginsky M, Cohen MI, Finberg L 1976 25-hydroxycholecalciferol in the management of rickets associated with extrahepatic biliary atresia. J Pediatr 88:1041-1043

10. Heubi JE, Hollis BW, Tsang RC 1989 Bone disease in chronic childhood cholestasis. II. Better absorption of $25-\mathrm{OH}$ vitamin $\mathrm{D}$ than vitamin $\mathrm{D}$ in extrahepatic biliary atresia. Pediatr Res 27:26-31

11. Traber MG, Kayden HJ, Green JB, Green MH 1986 Absorption of watermiscible forms of vitamin $E$ in a patient with cholestasis and in thoracic duct-cannulated rats. Am J Clin Nutr 44:914-923

12. Melhorn DK 1973 Vitamin E: who needs it? II. Diseases associated with vitamin E deficiency. Ohio State Med J 69:830-833

13. Sokol RJ, Heubi JE, Butler-Simon N, McClung HJ, Lilly JR, Silverman A 1987 Treatment of vitamin E deficiency during chronic childhood cholestasis with oral $d$-alpha-tocopheryl polyethylene glycol-1000 succinate. Gastroenterology 93:975-985

14. Lo CW, Paris PW, Clemens TL, Nolan J, Holick MF 1985 Vitamin D absorption in healthy subjects and in patients with intestinal malabsorption syndromes. Am J Clin Nutr 42:644-649

15. Hollis BW, Frank NE 1985 Solid phase extraction system for vitamin D and its major metabolites in human plasma. J Chromatogr 343:43-49
16. Heubi JE, Sokol RJ, McGraw CA 1990 Comparison of total serum lipids measured by two methods. J Pediatr Gastroenterol Nutr 10:468-472

17. Rubenstein HM, Dietz AA, Srinavasan R 1969 Relation of vitamin E and serum lipids. Clin Chim Acta 23:1-6

18. Horwitt MK, Harvey CC, Dahm CH, Searcy MT 1972 Relationship between tocopherol and serum lipid levels for determination of nutritional adequacy. Ann NY Acad Sci 203:223-236

19. Farrell PM, Levine SL, Murphy D, Adams AJ 1978 Plasma tocopherol levels and tocopherol-lipid relationships in a normal population of children as compared to healthy adults. Am J Clin Nutr 31:1720-1726

20. Bieri JG, Poukka ER, Thorp S 1977 Factors affecting the exchange of tocopherol between red blood cells and plasma. Am J Clin Nutr 30:686-690

21. Specker BL, Brazerol W, Tsang RC, Levin R, Searcy J, Steichen J 1987 Bone mineral content in children 1 to 6 years of age. Am J Dis Child 141:343344

22. Schumaker RC 1986 PKCALC: a basis interactive computer program for statistical and pharmacokinetic analysis of data. Drug Metabol Rev 17:331348

23. Weber $F 1981$ Absorption mechanisms for fat-soluble vitamins and the effect of other food constituents. Prog Clin Biol Res 77:1 19-135

24. Hollander D 1981 Intestinal absorption of vitamins A, E, D, and K. J Lab Clin Med 97:449-462

25. Friedman HI, Nylund B 1980 Intestinal fat digestion, absorption, and transport: a review. Am $J$ Clin Nutr 33:1 108-1139

26. Hollander D, Muralidhara KS, Zimmerman A 1978 Vitamin $D_{3}$ intestinal absorption in vivo: influence of fatty acids, bile salts, and perfusate $\mathrm{pH}$ on absorption. Gut 19:267-272

27. Heymann W 1937 Metabolism and mode of action of vitamin D. IV. Importance of bile in the absorption and excretion of vitamin D. J Biol Chem 122:249-256

28. Taylor NB, Weld CB, Sykes JF 1935 The relation of bile to the absorption of vitamin D. J Exp Pathol 16:302-309

29. Hollander D 1976 Mechanism and site of small intestinal uptake of vitamin $D_{3}$ in pharmacological concentrations. Am J Clin Nutr 29:970-975

30. Daniellson A, Lorentzon R, Larsson SE 1982 Intestinal absorption and 25hydroxylation of vitamin $\mathrm{D}$ in patients with primary biliary cirrhosis. Scand J Gastroenterol 17:349-355

31. Meredith SC, Rosenberg IH 1980 Gastro-intestinal hepatic disorders and osteomalacia. J Clin Endocrinol Metab 9:131-140

32. Krawitt EL, Grundman MJ, Mawer EB 1977 Absorption, hydroxylation, and excretion of vitamin $\mathrm{D}_{3}$ in primary biliary cirrhosis. Lancet 2:1246-1249

33. Sokol RJ, Heubi JE, Iannaccone ST, Bove KE, Balistreri WF 1983 Mechanisms causing vitamin $\mathrm{E}$ deficiency during chronic childhood cholestasis. Gastroenterology 85:1172-1182

34. Imai J, Hayashi M, Awazu S, Hanano M 1983 Solubilization of $d$ l-alphatocopherol by bile salts, polysorbate 80 and egg lecithin. Chem Pharm Bull (Tokyo) 31:4077-4082

35. Reed JS, Meredith SC, Nemchausky BA, Rosenberg IH, Boyer JL 1980 Bone disease in primary biliary cirrhosis: reversal of osteomalacia with oral 25. hydroxyvitamin D. Gastroenterology 78:512-517

36. Lichtenstein P, Specker BL, Tsang RC, Mimouni F, Gormley C 1986 Calciumregulating hormones and minerals from birth to 18 months of age: a crosssectional study. I. Effects of sex, race, age, season, and diet on vitamin D status. Pediatrics 77:883-890

37. Sokol RJ, Karrer FM, Narkewicz MR, Johnson KE, Schroter GPJ, Kam I 1990 Use of water-soluble vitamin $E$ to improve cyclosporine (CS) absorption in pediatric liver transplantation patients. Hepatology 12:865(abstr) 